\title{
Bush and Congress set debate on priorities
}

President George W. Bush's vision of America's science priorities, as revealed in his budget request for fiscal year 2008, is pretty much the same as it was last year. But one crucial thing has changed: the Democrats are now in charge of Congress, and they are the ones who get to decide whether his request becomes reality.

When it received the president's request on 5 February, Congress was already in the process of ladling out an extra $\$ 620$ million for biomedical research in the current year, enough for the president's 2008 request to actually represent a cut. Bush has focused instead on increasing funding for the physical sciences under the second year of a 'competitiveness initiative' to stimulate investment in science and engineering. Overshadowing all such requests is the war in Iraq and the global war on terror, for which Bush is requesting $\$ 142$ billion for 2008.

Meanwhile, US researchers continue to deal with the messy leftovers of last year's budget process, of which the biomedical science boost forms a part. The budget process ground to a halt in December when the old, Republicanled Congress left without finalizing budget bills for fiscal year 2007. Soon, though, the current Congress is expected to pass a sort of halfway budget for 2007, which would keep most agencies at their 2006 spending levels but make adjustments for some. The House of Representatives passed this bill on 31 January and the Senate is expected to do so by 15 February.

This week, Bush asked Congress to give the National Institutes of Health (NIH) \$28.7 billion in $2008-\$ 232$ million of it new money compared with 2006 levels. But of that, $\$ 200$ million would have to be transferred to the Global Fund to Fight HIV/AIDS, Tuberculosis and Malaria. That means, in effect, that Bush's request would cut the agency budget by roughly half a billion dollars, or $1.7 \%$ in 2008.

\section{Health check}

Elias Zerhouni, the NIH director, said he was pleased with both the congressional action and Bush's budget request. "I personally feel that there has been a huge turnaround - that Congress has regained confidence in the NIH," he said. "The same thing is true of this administration."

Research advocates weren't so upbeat. David Moore, a lobbyist at the Association of American Medical Colleges, says that his group has been encouraged by Congress approving the

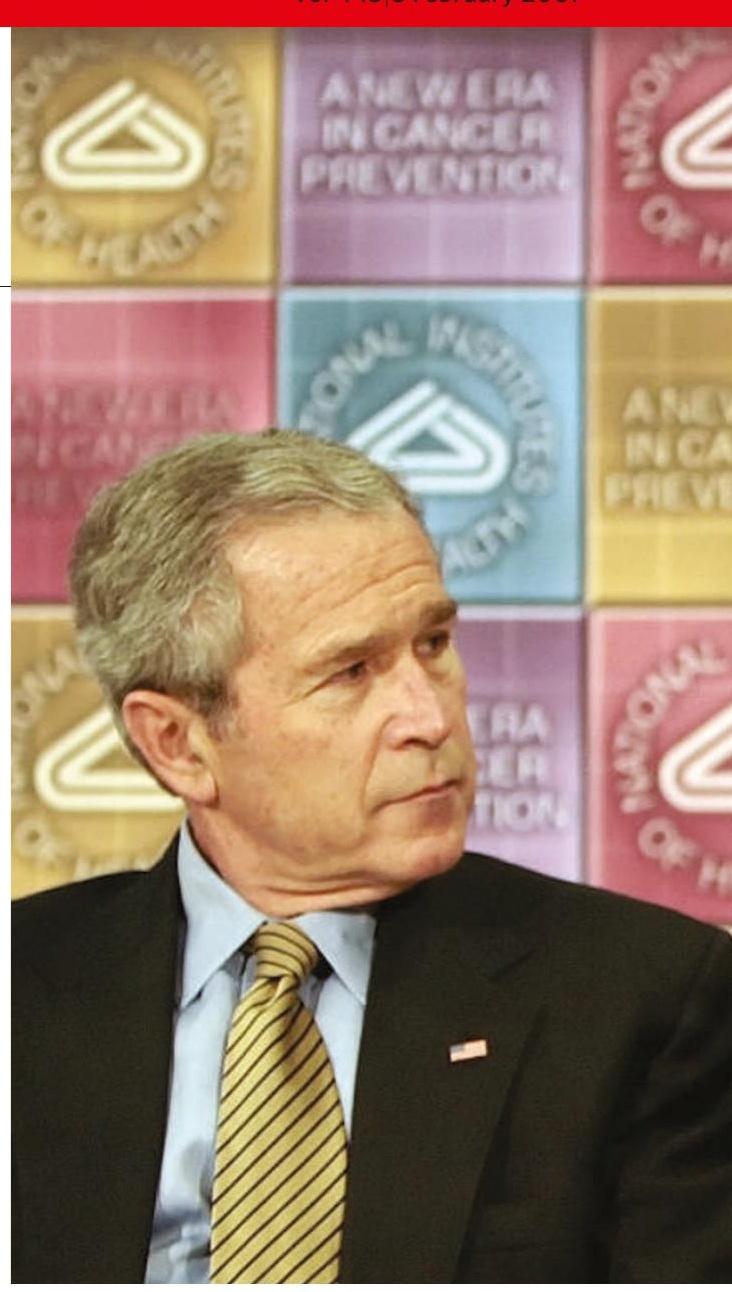

NIH director Elias Zerhouni (right) feels President Bush's budget recognizes his agency's true role.

extra money for 2007. "We're equally discouraged with the administration's budget," he adds, "which essentially puts the NIH right back in the hole again."

But Congress may boost the agency's budget further in 2008. The key congressional appropriators in both chambers of Congress are strong NIH advocates. And last month, Bush

\begin{tabular}{|c|c|c|c|c|}
\hline Agency & $\begin{array}{c}2006 \\
\text { (actual) }\end{array}$ & $\begin{array}{l}2007 \\
\text { (likely) }\end{array}$ & $\begin{array}{c}2008 \\
\text { (president's request) }\end{array}$ & Notes \\
\hline National Institutes of Health & 28,359 & 28,979 & 28,700 & $\begin{array}{l}\text { An additional } \$ 158 \text { million from other government sources, for diabetes research and the } \\
\text { National Library of Medicine, will be provided in } 2008 \text { but is not included in the request } \\
\text { at left. }\end{array}$ \\
\hline National Science Foundation & 5,590 & 5,916 & 6,430 & $\begin{array}{l}\text { Restored funds for } 2007 \text { may allow the United States to participate in the International } \\
\text { Polar Year as planned. A new petascale computing centre is also in the works. }\end{array}$ \\
\hline $\begin{array}{l}\text { Department of Energy's Office of } \\
\text { Science }\end{array}$ & 3,633 & 3,796 & 4,398 & $\begin{array}{l}\text { Much of the proposed boost is related to the American Competitiveness Initiative to } \\
\text { foster innovation. Also includes funds for several biofuel research centres. }\end{array}$ \\
\hline NASA & 16,273 & 16,247 & 17,310 & $\begin{array}{l}\text { Plans to replace the space shuttle are likely to have to move more slowly than planned } \\
\text { because of expected cuts for } 2007 \text {. }\end{array}$ \\
\hline $\begin{array}{l}\text { National Oceanic and Atmospheric } \\
\text { Administration }\end{array}$ & 3,851 & 3,851 & 3,812 & $\begin{array}{l}\text { The president called for more funding for ocean research in late January, but the agency } \\
\text { would still face cuts under his } 2008 \text { request. }\end{array}$ \\
\hline $\begin{array}{l}\text { National Institute of Standards and } \\
\text { Technology (core funding) }\end{array}$ & 431 & 491 & 594 & $\begin{array}{l}\text { Although core funding, for science and related construction projects, is increased, the } \\
\text { zeroing out of congressionally mandated projects or earmarks, means that the total } 2008 \\
\text { budget goes down for the agency. }\end{array}$ \\
\hline Environmental Protection Agency & 7,619 & 7,619 & 7,200 & The EPA's budget continues to be eroded. \\
\hline US Geological Survey & 958 & 978 & 975 & $\$ 3$ million of the increase for 2007 will be for ocean science programmes. \\
\hline $\begin{array}{l}\text { Department of Defense (basic \& } \\
\text { applied research) }\end{array}$ & 6,405 & 6,893 & 5,785 & $\begin{array}{l}\text { The Defense Advanced Research Projects Agency budget for } 2008 \text { shrinks by } 1 \% \text { to } \\
\$ 3.1 \text { billion. }\end{array}$ \\
\hline $\begin{array}{l}\text { Homeland Security (science \& } \\
\text { technology) }\end{array}$ & 1,467 & 848 & 799 & Funds are shifting to a new office for detecting nuclear and radiological threats. \\
\hline
\end{tabular}


